\title{
Hvor ble det av diskusjonen om bioteknologiloven?
}

Endringene som ble besluttet i bioteknologiloven, åpner for mange muligheter for enkeltindividet og samfunnet, men i samme åndedrag oppstår det også noen etiske dilemmaer.

\section{Mildrid Haugrønning Søndbø}

Leder

Rådet for sykepleieetikk

Bioteknologiloven

Etikk

Barn

Sykepleien 2020108 (82285) (e-82285)

DOI: 10.4220/Sykepleiens.2020.82285

Bioteknologiloven er vedtatt. Eggdonasjon, assistert befruktning for enslige, tidlig ultralyd og blodprøven NIPT, som gjør det mulig å avlese mulige kromosomfeil, som Downs syndrom tidlig i svangerskapet, er nå tilgjengelig.

Bruk av nedfryst sæd fra avd $\varnothing$ de, lagring av befruktede egg og lagring av kjønnsceller på ikke-medisinsk grunnlag er også nytt. Dette er noen av endringene i bioteknologiloven, som ble vedtatt 26. mai. 


\section{Genteknologi skaper etiske dilemmaer}

Utvikling av genteknologi skjøt fart på 1970-tallet ettersom forskerne da hadde mulighet til å gå inn og gjøre endringer i organismens arvemateriale (DNA). Genteknologi gir et hav av muligheter, men skaper også en del etiske dilemmaer. Det er derfor viktig med et klart regelverk i alle delene av denne loven. Forskere kan også misbruke samfunnets tillit.

\section{«Forskere kan også misbruke samfunnets tillit.»}

Det er mange som har kjempet for, og mange har kjempet mot, lovendringen. Denne virkeligheten speiler også avstemningen i Stortinget, noe som viser at loven ikke har bred forankring.

\section{Vi må ikke la diskusjonen stilne}

Rådet for sykepleieetikk ble ikke bedt om å levere høringsinnspill før lovendringene ble vedtatt. Jeg uttaler meg derfor ut fra egne refleksjoner og ikke på vegne av hele Rådet.

Morten Magelssen er lege og medlem i Bioteknologirådet. Han uttalte 20. juni til magasinet Norge $i$ dag:

«Vi har diskutert disse spørsmålene i hui og hast. Det har vært utilfredsstillende fordi vi ikke har fått den grundige diskusjonen oss imellom og heller ikke fått ut et dokument til offentligheten, som er så grundig og gjennomarbeidet som det $b \varnothing r$ være.»

Dette er kanskje den lovendringen i nyere tid som har flest ukjente konsekvenser. Derfor må ikke diskusjonen stilne av.

\section{Det handler om mulighetene til å hjelpe}


Det aller viktigste i livet er for mange å få barn. Det er derfor av stor betydning at flere kan få hjelp til å få dette $\varnothing$ nsket innfridd. Likevel er det riktig å løfte diskusjonen. Dette handler om noe mer. Det handler om helsevesenets muligheter til å hjelpe, da vi vet at det mangler kritisk mange jordmødre nå i 2020 . Ja, faktisk så mange at pasientsikkerheten kan stå i fare.

I sin årlige sykehustale 15. januar i år viste Bent Høie til Riksrevisjonens rapport, som har avdekket at så mye som 40 prosent av rekrutteringen av jordm $\varnothing$ dre ikke ga noe resultat.

\section{«Pasientsikkerheten står i fare på de største fødeavdelingene.»}

Vi vet at jordmødre utfører svangerskapskontroller på alle gravide, de følger opp i forbindelse med abort, og de utfører rutinemessig ultralyd. Det handler derfor om både prioriteringer og om muligheter da jordm $\varnothing$ drene er en helt sentral akt $\varnothing$ r. Loven gir konsekvenser for barnet, og det handler om holdninger til mennesker med kromosomavvik.

\section{Foreldre må vite hva testen gir svar på}

Livet er et usikkert prosjekt. Vi vet ikke hva som hender oss. Det er viktig at alle blivende foreldre har en riktig oppfatning av hva NIPT- testen gir av svar.

Det er ikke nøyaktig oversikt over hvor mange barn og unge vi har med nedsatt funksjonsevne, men ifølge Statistisk sentralbyrå (SSB) har vi mellom 17000 og 20 000. Kromosomavvik utgjør bare en svært liten andel. Hva skjer med foreldre som får barn med nedsatt funksjonsevne, tross tester?

\section{Diskusjonen må settes på dagsordenen}


Etiske dilemmaer fortjener en opplyst og åpen diskusjon, da et dilemma oppstår når den beste løsningen ikke er helt selvsagt. Denne kompleksiteten må erkjennes, og politikere, ulike organisasjoner og mediene bør ta ansvar for å sette diskusjonen på dagsordenen.

\section{«En opplyst diskusjon skal kaste lys over vanskelige områder i livet.»}

En opplyst diskusjon skal kaste lys over vanskelige områder i livet. Argumentene hjelper oss til å skille gode innspill fra de mindre gode. Hvilke synspunkter og avgjørelser er bedre enn andre? Argumenter stimulerer til videre unders $\varnothing$ kelser. Vi får et bedre grunnlag for å ta de rette valgene.

Jeg har stor tillit til jordmødrenes stemme da de kan bidra til åpne og konstruktive diskusjoner. Jordmødrene kommer tett på blivende foreldre som kan oppleve vanskelige dilemmaer. De er i en absolutt særstilling når det gjelder dette temaet. Hva er deres erfaringer? Er det lagt til rette for nok informasjon for alle parter, og hvem kan de dele etiske dilemmaer med?

\section{I en god diskusjon nærmer vi oss andre}

Når vi diskuterer for eller imot en sak, er det mange av oss som har oppdaget at visse fakta eller synspunkter er verdifulle å ta med seg videre, forhold vi ikke hadde tenkt på, og som det blir viktig å utforske.

Utgangspunktet for den etiske refleksjonen er å innlemme alle de forhold som er aktuelle, selv om det kan være ubehagelig. Hvem vil berøres av denne lovendringen? På hvilken måte? Hvordan vil barna som en part oppleve det? Våre argumenter uttrykker hva vi bryr oss om.

\section{«Det høyner ikke diskusjonen om vi behandler andre som en ting som kan manipuleres.»}


I en god diskusjon nærmer vi oss andre som autonome mennesker, som er i stand til å tenke selv. Det høyner ikke diskusjonen om vi behandler andre som en ting som kan manipuleres ved retoriske knep eller ved ikkeverbale nedlatende uttrykk.

\section{Det vil være ulike oppfatninger}

Det vil alltid være ulike oppfatninger i dette kompliserte terrenget. Derfor er diskusjonen og refleksjonen så viktig.

Helseminister Bent Høie har som ett av sine mål i oppdragsdokumentet for sykehusene, at kvaliteten og pasientsikkerheten skal bli enda bedre i 2020. Det innebærer at vi må lære av dem som står midt i valgmulighetene, og vi må lære av helsepersonell som står nært denne gruppen.

Helsevesenet vil få en mulighet til å navigere etter de beste løsningene og oppmuntre til valg hver enkelt kan bære. Psykologer, filosofer og teologer kan også bidra med kunnskap om det å være menneske og konsekvenser av valg.

\section{Foreldre sliter seg ut på byråkrati}

Det vil alltid fødes barn med ekstra behov. Her har alle som kjemper for et inkluderende samfunn med plass til alle, en stor oppgave og påvirkningsmulighet. Vi vet at enkelte får tilfredsstillende hjelp, men langt ifra alle.

Det er uakseptabelt at foreldre sliter seg ut på byråkrati i en situasjon vi andre ikke har mulighet til å sette oss inn i. Nok er nok. Her burde kanskje alle som mener at det må være plass til alle, vise sitt engasjement.

\section{«Det er uforståelig at det offentlige har klart å produsere et skjemavelde som tar fullstendig energien fra foreldrene.»}


For en del år tilbake var det egne institusjoner for ulike funksjonsnedsettelser. Nå bor de aller fleste hos sine foreldre, noe som både er bra og krevende. Det er uforståelig at det offentlige har klart å produsere et skjemavelde som tar fullstendig energien fra foreldrene. Dette er et stort etisk og praktisk problem som må ordnes opp i.

Alt unødvendig byråkrati må bort, da foreldrene selv vet det beste for barnet sitt. Som foreldre er vi ulike, derfor må hjelpen være skreddersydd.

\section{Sykepleieren skal ivareta pasientens verdighet}

Sykepleiens grunnlag er respekten for det enkelte menneskets liv og iboende verdighet. Dette skal være førende i møte med alle pasienter da sykepleie har lange og gode tradisjoner som skal bære i alle livets vanskelige øyeblikk.

I Yrkesetiske retningslinjer for sykepleiere er det også klart definert at «[s]ykepleieren ivaretar pasientens verdighet og sikkerhet i møte med den teknologiske og helsepolitiske utvikling».

Som sykepleiere er vår oppgave uansett i dette landskapet å ivareta og støtte opp om pasientens verdighet og overbevisning. 